\title{
Valorization of pikliz: a spicy meal garnishment in Haitian cuisine
}

\author{
James Louis-Jean ${ }^{1 *}$ (D), Debbie Sanon ${ }^{2}$, Kevin Louis-Jean ${ }^{3}$, Nicole Sanon², Ruthonce Stvil Louis-Jean ${ }^{4}$ and \\ Michelle Luvy Thomas ${ }^{5}$
}

\begin{abstract}
The biochemical process of fermentation (zymology) is widely practical for foods and beverages. This metabolic process involves microorganisms (bacteria) and their enzymes in the preparation and preservation of foods. Many studies have shown that fermented foods and beverages have various documented health benefits to humans, such as being high in vitamin b, and, among other benefits, having atherogenic and anticarcinogenic properties. This communication discusses the significance of fermentation in Haitian cuisine by focusing on pikliz-a spicy fermented meal garnishment that is widely popular among Haitian dishes. This analysis provides relevant information on Haitian cuisine while examining the underlying mechanisms, compositions, properties, nutritional values, and potential health benefits of pikliz. This spicy meal garnishment represents the regional, ethnic, and national identity of Haitians living in Haiti and abroad.
\end{abstract}

Keywords: Cabbage, Carrot, Fermentation, Haitian cuisine, Pikliz

\section{Introduction}

Historical overview of Haitian cuisine

Prior to the Europeans' arrival to the Caribbean island of Ayiti, otherwise known as Ayiti Quisqeya (present-day Haiti and Dominican Republic), the island was inhabited by the native indigenous people, called the Taino $[1,2]$. At the time, the island (Fig. 1) was divided into five regions: Magua, Marien, Jaragua, Maguana, and Higüey, where each region was governed by a Cacique-Taino Chief. As Christopher Columbus took possession of the island in 1492, he renamed it to La Isla Española, which was later changed to Hispaniola [3]. The Spanish ruled the island from 1492 to 1625 , where later, the French received and established their colony in the western region, historically called Saint Domingue and is present-day Haiti (Fig. 1). The Frenchmen oppressed Haiti by creating a slavery-based agricultural system used to exploit the richness of the land. They did so by importing a vast number of Africans to the island and

\footnotetext{
* Correspondence: louisjea@unlv.nevada.edu; james.louisjean@yahoo.com

${ }^{1}$ University of Nevada Las Vegas, Las Vegas, NV, USA

Full list of author information is available at the end of the article
}

forced them to work as slaves under harsh conditions in various plantations (i.e., coffee, sugar, cocoa, tobacco indigo, and cotton among others). Nonetheless, the slaves revolted and gained their independence from France in 1804. Following the Haitian Revolution, the influences of the various ethnic groups who populated the island remained evident in the Haitian society-from the language to the cuisine.

The culinary blend of the African, French, Taino, and Spanish cultures helped to develop and establish the nature of Haitian cuisine [4] along with the later influences from Levantines, due to Arab migration over the years [5]. For instance, the Taino natives first introduced barbecue, or barbeque (BBQ), to Haitian cuisine, then to the world. The Africans introduced okra, also called gumbo (kalalou), and other various vegetables roots (i.e., yam, taro, and cassava), fruits, and spices. As for Spanish influence, it is well known that the style and technique of Haitian cooking are similar to those of Latin America, but with many technical variations. Haitian food independently maintains a unique flavor compared to its Latin Caribbean counterparts.

(c) The Author(s). 2021 Open Access This article is licensed under a Creative Commons Attribution 4.0 International License, which permits use, sharing, adaptation, distribution and reproduction in any medium or format, as long as you give appropriate credit to the original author(s) and the source, provide a link to the Creative Commons licence, and indicate if changes were made. The images or other third party material in this article are included in the article's Creative Commons licence, unless indicated otherwise in a credit line to the material. If material is not included in the article's Creative Commons licence and your intended use is not permitted by statutory regulation or exceeds the permitted use, you will need to obtain permission directly from the copyright holder. To view a copy of this licence, visit http://creativecommons.org/licenses/by/4.0/. 


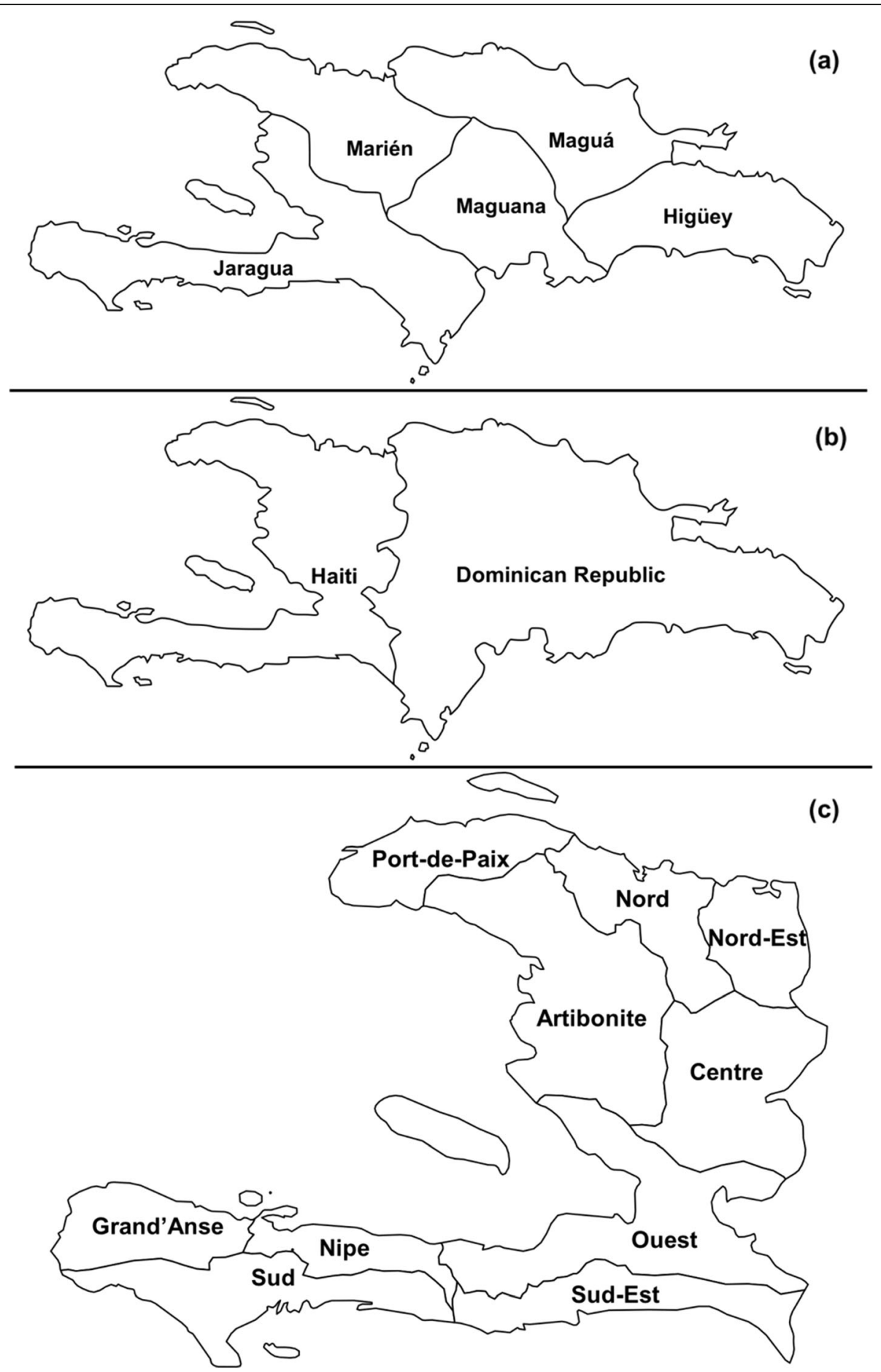

Fig. 1 Map showing Hispaniola as divided into five Cacique regions prior to Columbus (a), present-day Haiti and Dominican Republic (b), and map showing only the administrative divisions of present-day Haiti's ten departments (c)

Haitian cuisine is largely based on the liberal use of epis-an assortment of herbs and spices. A typical epis consists of garlic, green onion, thyme, salt, and pepper, all crushed to form a paste-like mixture. It is generally used to season and prepare all types of meat, seafood, légume (a thick vegetable stew), bean purée (sauce pois, sòs pwa), rice (diri kole; diri djon-djon), and Haitian spaghetti among other dishes. Although the form of epis differs among cuisines, its use is an essential requirement in Haitian cuisine, Creole cuisine. 
Since typical Haitian religions, like Christianity and Voodoo, are important aspects of the culture, several dishes are typically prepared for religious gatherings and celebrations. The same applies to cultural holidays such as Haiti's Independence Day, where the freedom from slavery is celebrated through pumpkin soup (soup joumou). Of all the mentioned dishes and many others, they are not complete until a lump sum of pikliz is accompanied beside each meal. While the origin of piklizhistorically remains unknown, this spicy meal garnishment represents the regional, ethnic, and national identity of Haitians living in Haiti and abroad. As the population of Haitians who reside outside the country continues to increase, they continue to represent and share their culture and cuisine to the world. In the USA, Canada, and France, where a majority of Haitians reside, the annual Haitian Food Festival is considered an important event for Haitians to share and celebrate the richness of their cuisine.

\section{Pikliz and its process Understanding pikliz}

The name pikliz (pronounced PEE-kleez) can be understood based on the word pickle and the French word piquer (meaning to sting). Pickle is derived from the Dutch word pekel and from the Northern German word pókel (both meaning brine). The pickling process preserves and extends the lifespan of food through a process known as anaerobic fermentation, where food is soaked in in a brine solution or vinegar solution for a long period of time [6]. Meat, fish, eggs, and vegetables are commonly and historically known to have systematically undergone pickling. This process not only preserves the food, but it also affects the taste, flavor, and texture of the food. In various regions of the world, the term pickle is typically referred to pickled cucumber, egg, or onion. While the origin of pickling remains unknown, credit is given to the ancient Indus Valley Civilization of the Mohenjo Dara (Northwest of the Indian continent) about $2400 \mathrm{BC}$.

Pickling remains as one of the oldest methods used for food preservation, found in many parts of the world. Such process is said to have been brought to Hispaniola during the European exploration age, and emerged into Haitian cuisine in the form of pikliz. Pikliz is a condiment made from shredded cabbage and carrot mixed with an extensive amount of peppers (piment) and spices, all immersed in vinegar or lemon juice [7-9]. The nature of this process can be chemically explained by the production of lactobacillus plantarum; and of alcohols and acids which form aromatic compounds from leuconostoc mesenteroides during fermentation [10]. These bacteria species, lactobacillus and leuconostoc, are associated with fermentation under salinity condition in high and low temperatures, respectively. The acidity media ( $\mathrm{pH} 4$ or lower) [11] and the antimicrobial properties of the spices [12] serve to preserve and kill most bacteria in the pikliz while enhancing its flavor during fermentation. Overall, the acidity and salinity of the solution from the vinegar and spices along with the temperature of fermentation regulate the microorganism species, which determine the final flavor of the pikliz.

This spicy fermented meal garnishment, pikliz, has long been prepared at the household level in Haiti; however, as the number of Haitians living abroad continues to increase, commercialization of pikliz on an industrial level has systematically increased (Fig. 2). Nowadays, pikliz can be purchased at major supermarkets in the USA, such as Walmart ${ }^{\circ}$, Publix Market ${ }^{\circ}$, and other regional supermarkets (Fig. 2). Altogether, pikliz remains the symbol of Haitian culture (Figs. 3 and 4).
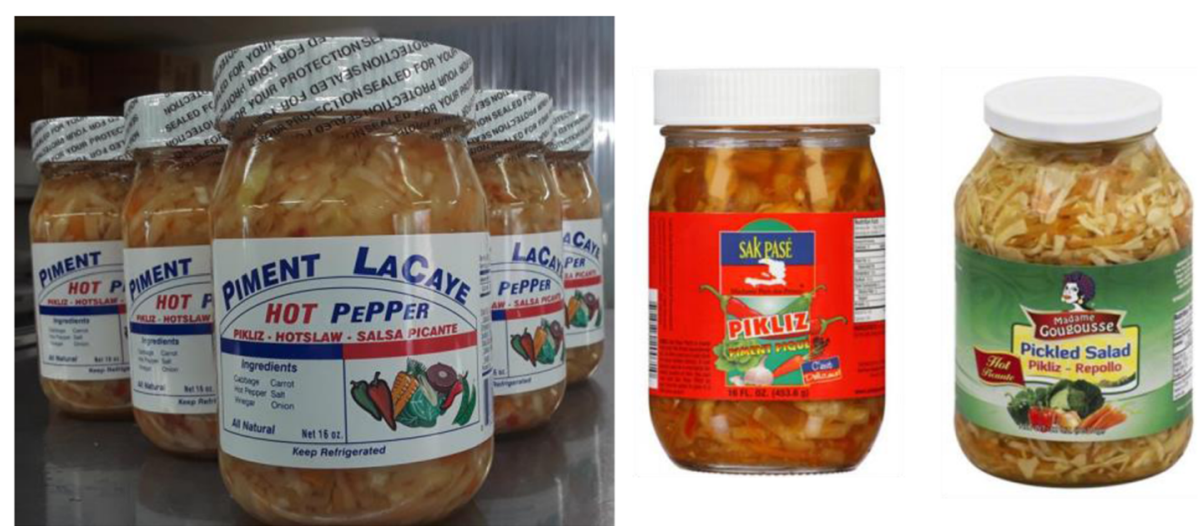

Fig. 2 Selected photographs of various pikliz brands available at designed grocery stores and online markets [13-15] throughout the USA as commercialization of pikliz continues to increase among Haitians living at home and abroad 


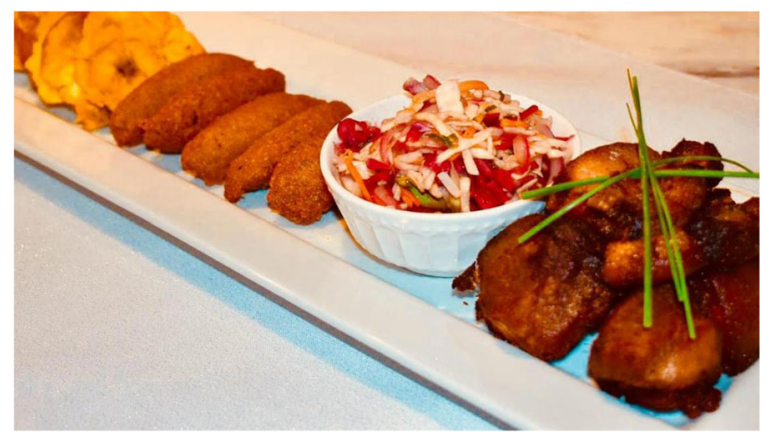

Fig. 3 A typical Haitian meal (fritay) served with pikliz. Left to right: fried plantain (bannann peze), malanga fritters (akra), pikliz, and fried pork (griyo) as prepared by Manje, a Caribbean fusion catering service in Fargo, North Dakota [16]

\section{Dissecting pikliz components Cabbage-Brassica oleracea}

Cabbage, a member of genus Brassica and Brassicaceae (mustard family), is high in nutritional value [17]. A $100 \mathrm{~g}$ size of raw cabbage (Table 1) contains vitamin C (44\%), vitamin K (72\%), vitamin B (35\%); (Table 2) various minerals (i.e., zinc and potassium, 1-8\%) and some of $103 \mathrm{~kJ}$ (25 kcal) of energy (Table 4) [18]. The pickling process could improve the nutritional value of the cabbage (B vitamins) which is produced by bacteria [19]. These vitamins are water-soluble and are necessary for cell metabolism.
Cabbage can be prepared in various ways for consumption. This includes steaming, stew, sautée, braise, and pickle. The pickling method (Table 3) remains most popular for pikliz in Haitian cuisine; sauerkraut in Azerbaijani, Belarusian, Polish, Russian, Baltic states, and Ukrainian cuisine; kimchi in Korean cuisine; suan cai in Chinese cuisine; and curtido in Salvadorian cuisine and other Central American cuisines [17, 20-22].

Although cabbage has been cultivating around 1000 $\mathrm{BC}$ [23] in central and western Europe and introduced to America around the 1540s [24], scientists are not yet able to fully study the health benefits of cabbage. As the plant consists of sulforaphane and glucosinolate, phytochemical studies of cabbage to understand the health benefits and anti-disease properties of the plant are undergoing. The plant also serves as a great source of indole-3-carbinol [25]. These compounds could stimulate metabolism from the production of detoxifying enzymes [26]. Such cruciferous plant could also have protective effects against colon cancer [27], among other properties related to antioxidant [28], anti-atherogenic, and anticarcinogenic [29]. These properties are subjects of ongoing biomedical research [25].

\section{Carrot-Daucus carota sativus}

Carrot is a root vegetable belonging to the Apiaceae family which consists of mostly aromatic flowering
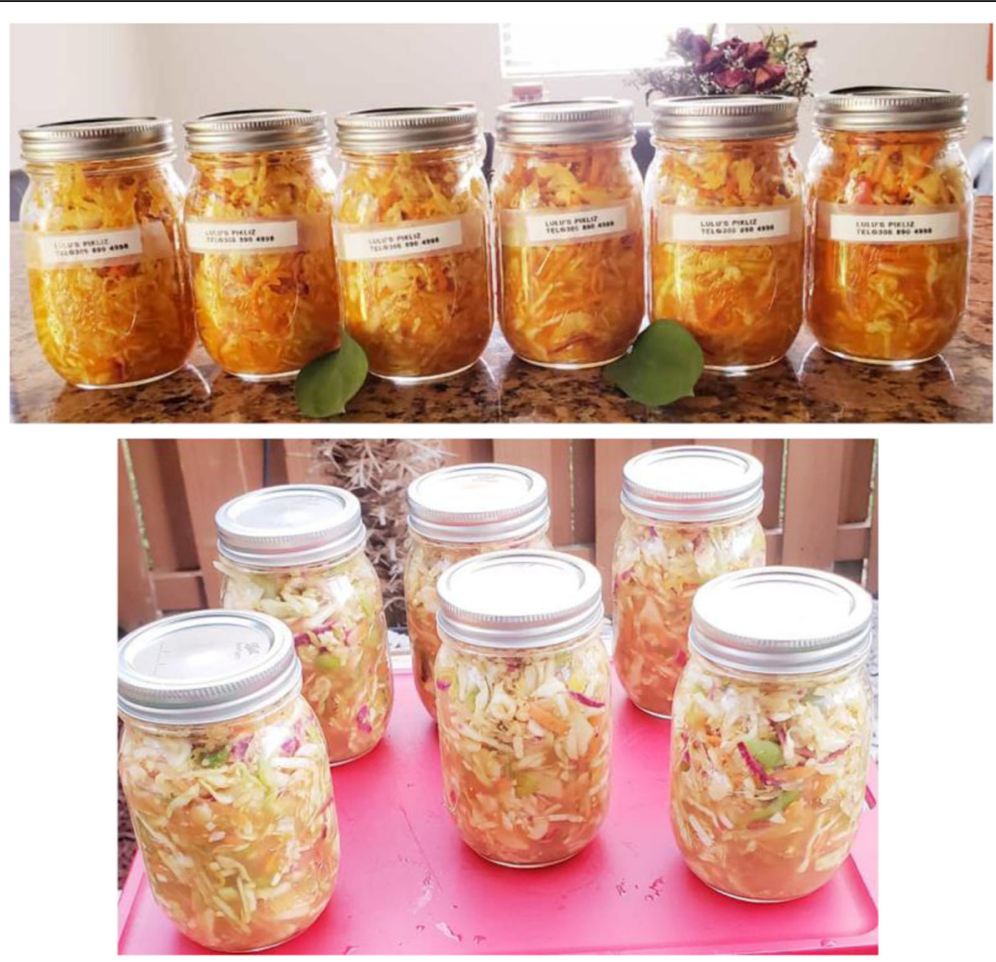

Fig. 4 Photographs of homemade pikliz as prepared using traditional family recipe and stored in sealed containers for fermentation. This process enhances the flavor of the pikliz, preserves its contents, and increases the lifespan of the pikliz 
Table 1 Comparative vitamins data showing nutritional value per $100 \mathrm{~g}$ of raw material (cabbage and carrot) based on the data reported by United States Department of Agriculture (USDA)

\begin{tabular}{llllll}
\hline Vitamins & \multicolumn{2}{l}{ Cabbage } & & \multicolumn{2}{l}{ Carrot } \\
\cline { 2 - 3 } & Mass $^{\mathbf{a}}$ & DV $^{\mathbf{b}}$ & & Mass $^{\mathbf{a}}$ & DV $^{\mathbf{b}}$ \\
\hline Vitamin A & - & - & $835 \mu \mathrm{gg}$ & $104 \%$ \\
Beta carotene & - & - & $8.285 \mathrm{mg}$ & $77 \%$ \\
Lutein zeaxanthin & - & - & $0.256 \mathrm{mg}$ & - \\
Thiamine (B1) & $61 \mu \mathrm{g}$ & $5 \%$ & $66 \mu \mathrm{g}$ & $6 \%$ \\
Riboflavin (B2) & $40 \mu \mathrm{g}$ & $3 \%$ & $58 \mu \mathrm{g}$ & $5 \%$ \\
Niacin (B3) & $0.234 \mathrm{mg}$ & $2 \%$ & $0.983 \mathrm{mg}$ & $7 \%$ \\
Pantothenic acid (B5) & $0.212 \mathrm{mg}$ & $4 \%$ & $0.273 \mathrm{mg}$ & $5 \%$ \\
Vitamin B6 & $0.124 \mathrm{mg}$ & $10 \%$ & $0.138 \mathrm{mg}$ & $11 \%$ \\
Folate (B9) & $43 \mu \mathrm{g}$ & $11 \%$ & $19 \mu \mathrm{g}$ & $5 \%$ \\
Vitamin C & $36.6 \mathrm{mg}$ & $44 \%$ & $5.9 \mathrm{mg}$ & $7 \%$ \\
Vitamin E & - & - & $0.66 \mathrm{mg}$ & $4 \%$ \\
Vitamin K & $76 \mu \mathrm{gg}$ & $72 \%$ & $13.2 \mu \mathrm{g}$ & $13 \%$ \\
\hline
\end{tabular}

${ }^{a}$ Mass are reported in milligrams $(\mathrm{mg})$ and micrograms $(\mu \mathrm{g})$

${ }^{b}$ Percentage daily value (DV) is based on USDA recommendations for adults. Food that provides $5 \%$ or less of the DV is considered a low source while food that provides $10 \%$ to $19 \%$ of the DV is a good source. Meanwhile, food that provides $20 \%$ or more of the DV is considered high in that nutrient. Refer to the USDA database for additional nutrient data

plants (i.e., umbelliferae). The word carrot is borrowed from French, carrotte, which first appeared in English in 1530. Carrotte itself is derived from Latin, carota, and

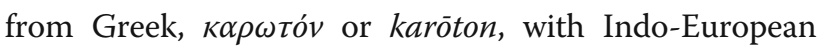
root word ker- (meaning horn; head). This can be explained by the horn-like shape of this cultivar. Various colors of the cultivar have been cultivated around the world. This includes black, white, red, and yellow-orange carrots (Fig. 5) [30-32]. Historically, the plant has been cultivated for its taproots, stems, and leaves

Table 2 Minerals and water contents per $100 \mathrm{~g}$ of raw material (cabbage and carrot) based on the recommended values for adults as reported by the USDA

\begin{tabular}{llllll}
\hline Minerals & \multicolumn{2}{l}{ Cabbage } & & \multicolumn{2}{l}{ Carrot } \\
\cline { 2 - 3 } \cline { 5 - 6 } & Mass $^{\mathbf{a}}$ & $\mathbf{D V}^{\mathbf{b}}$ & & Mass $^{\mathbf{a}}$ & $\mathbf{D V}^{\mathbf{b}}$ \\
\hline Calcium & $40 \mathrm{mg}$ & $4 \%$ & $33 \mathrm{mg}$ & $3 \%$ \\
Iron & $0.47 \mathrm{mg}$ & $4 \%$ & $0.3 \mathrm{mg}$ & $2 \%$ \\
Magnesium & $12 \mathrm{mg}$ & $3 \%$ & $12 \mathrm{mg}$ & $3 \%$ \\
Manganese & $0.16 \mathrm{mg}$ & $8 \%$ & $0.143 \mathrm{mg}$ & $5 \%$ \\
Phosphorus & $26 \mathrm{mg}$ & $4 \%$ & $35 \mathrm{mg}$ & $5 \%$ \\
Potassium & $170 \mathrm{mg}$ & $4 \%$ & $320 \mathrm{mg}$ & $7 \%$ \\
Sodium & $18 \mathrm{mg}$ & $1 \%$ & $69 \mathrm{mg}$ & $5 \%$ \\
Zinc & $0.18 \mathrm{mg}$ & $2 \%$ & $0.24 \mathrm{mg}$ & $3 \%$ \\
Water content & $92.6 \mathrm{~g}$ & - & $88 \mathrm{~g}$ & - \\
\hline
\end{tabular}

Legends $\left({ }^{a}\right.$ and ${ }^{b}$ ) are as described in Table 1 for the vitamins data
Table 3 Selected list of fermented cabbage food by similar processes that are found in various cuisines

\begin{tabular}{|c|c|}
\hline Name & Cuisine \\
\hline Pikliz & Haitian \\
\hline Sauerkraut & $\begin{array}{l}\text { Azerbaijani, Belarusian, Polish, Russian, Baltic states, } \\
\text { Ukrainian, and German }\end{array}$ \\
\hline Kimchi & Korean \\
\hline Suan cai & Chinese \\
\hline Curtido & Salvadorian \\
\hline Encurtido & Nicaraguan \\
\hline Tsukemono & Japanese \\
\hline $\begin{array}{l}\text { Kiseli kupus u } \\
\text { glavicama }\end{array}$ & Romanian, Bosnian, Croatian, Serbian, and Bulgarian \\
\hline Dill pickles & American, Eastern, and Central European \\
\hline Chow-chow & North American \\
\hline $\begin{array}{l}\text { Zasmażana } \\
\text { kapusta }\end{array}$ & Polish \\
\hline Choucroute & French \\
\hline
\end{tabular}

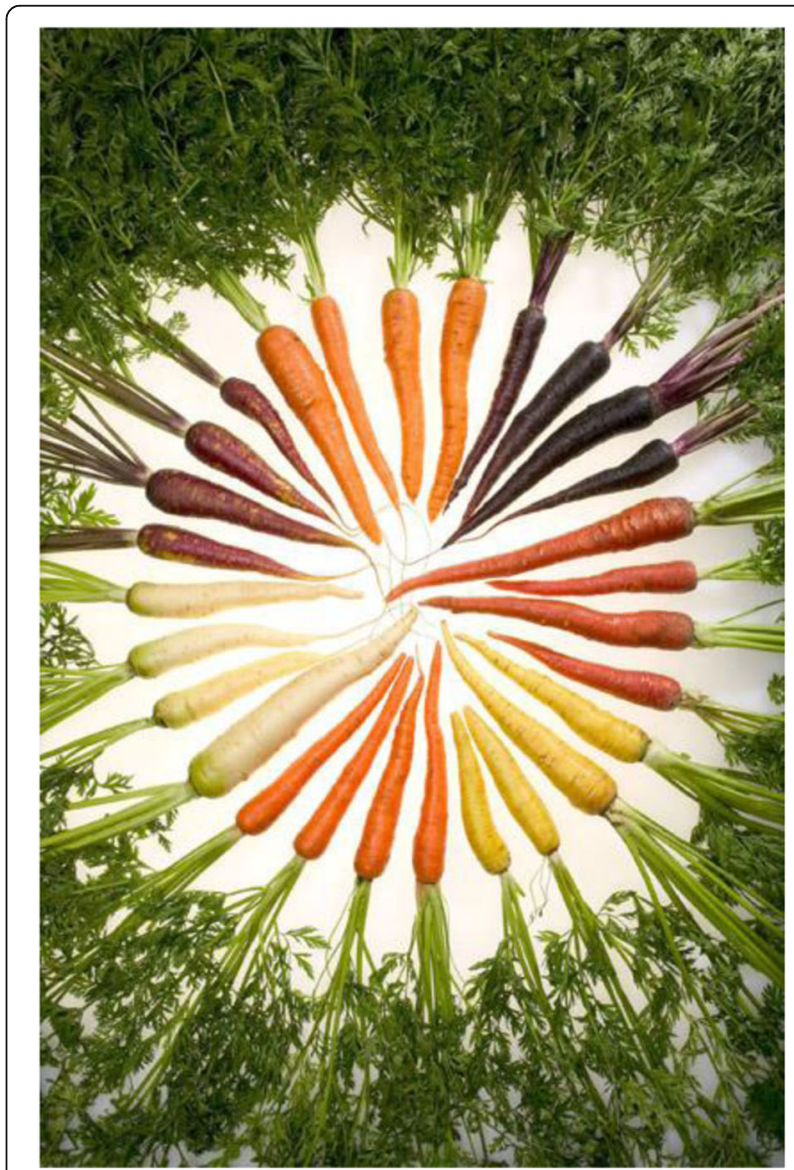

Fig. 5 Various colors of carrots selectively bred with pigments reflecting most of the colors of the rainbow by the Agricultural Research Service (ARS) under the USDA. See the link in ref. [30] for additional details 
consumption. While the green leaves are edible, they are seldomly consumed by humans due to their toxic naturally occurring alkaloid compounds [33-35]. Modern day carrot plants are selectively bred for a less wood-texture taproot. The vitamin contents (Table 1), mineral contents (Table 2) and nutritional values (Table 4) of carrots make the root of this cultivar very effective for a healthy diet. The root is a great source of vitamins (B6 and K) and contains a significant quantity of vitamin $\mathrm{A}$ and beta-carotene (provitamin A carotenoids). Carrot roots can be prepared in various ways for consumption. The root is widely used in various cuisines and can be boiled, steamed, fried, chopped (carrotte julienne), or pickled (i.e., pikliz and sauerkraut); in addition to the preparation of juice, salad, broth (mirepoix) [36], and even sweet dessert (i.e., carrot cake and carrot pudding). Carrots, as an Apiaceae, contain polyacetylene (oligoynes, carbinoids) compounds which exhibit cytotoxic activities [37, 38]. These compounds, namely, falcarinol and falcarindiol (cisheptadeca-1,9-diene-4,6-diyne-3,8-diol) show antifungal activity against mycocentrospora acerina and cladosporium cladosporioides [39]. The latter compound is also responsible for the bitterness of carrot root [40]. Meanwhile, other compounds such as 6-hydroxymellein [41], 6methoxymellein, eugenin, 2,4,5-trimethoxybenzaldehyde (gazarin), or (Z)-3-acetoxy-heptadeca-1,9-diene-4,6-diin8-ol (falcarindiol 3-acetate) are also present in carrots and in the leaves (pyrrolidine) [42].

While the repetitive idea 'carrot is good for your vision and it will make you see in the dark' is constantly being shared as a myth, such idea is only valuable to individuals who suffers from vitamin A deficiency. Such deficiency remains a major public health issue in developing countries [43]. Intake of animal and plant sources, such as fruits and vegetables (i.e., carrot, apricot, papaya, mango, sweet pepper) rich in bioactive compounds could greatly reduce the rate of nutrition-related chronic diseases $[44,45]$ in these countries. This vitamin has major health benefits and plays an important role in vision, reproduction, bone growth, cell differentiation, and cell division [46-50]. Vitamin A regulates the human

Table 4 Nutritional value per $100 \mathrm{~g}$ amount of raw material (cabbage and carrot) based on USDA recommendations for adults

\begin{tabular}{lll}
\hline & Cabbage & Carrot \\
\hline Energy & $103 \mathrm{~kJ}(25 \mathrm{kcal})$ & $173 \mathrm{~kJ}(41 \mathrm{kcal})$ \\
Carbohydrates (sum) & $5.8 \mathrm{~g}$ & $9.6 \mathrm{~g}$ \\
Sugar & $3.2 \mathrm{~g}$ & $4.7 \mathrm{~g}$ \\
Dietary fiber & $2.5 \mathrm{~g}$ & $2.8 \mathrm{~g}$ \\
Fat & $0.1 \mathrm{~g}$ & $0.24 \mathrm{~g}$ \\
Proteins & $1.28 \mathrm{~g}$ & $0.93 \mathrm{~g}$ \\
\hline
\end{tabular}

immune system as it helps to fight and prevent infections more effectively by the production of white blood cells, which destroys viruses and bacteria $[46,51-55]$. As nearly half of Haiti's population has no access to basic healthcare services and about $30-50 \%$ of the children are vitamin A deficient [56, 57], surprisingly, a high intake of pikliz could systematically improve their health. This idea is coupled with the aforementioned health benefits of the main constituent of pikliz (cabbage and carrot). The incorporation of carrots to rock buns-a traditional snack food in Ghana, is suggested to highly improve the nutritional value of the snack through the integration of vitamin A [58]. This idea is based on efforts to minimize the vitamin A deficiency problem among Ghanaians. While only $3 \%$ of the vitamin (in the form of alpha and beta-carotene) is accessible from raw consumption of carrots, researchers have shown that the bioavailability of provitamin A could be greatly improved to nearly $40 \%$ from softening or breaking down the cell wall of carrots (i.e., cooking, baking, the addition of oil, fermentation) [58-66].

\section{Conclusion}

While the pickling process-fermentation of food items-remains very efficient in preserving food, many cuisines have incorporated such process in achieving fermented food with significant health benefits. The chemical nature of this process is governed by the production of lactobacillus plantarum, and of alcohols and acids which form aromatic compounds from leuconostoc mesenteroides during fermentation. The production of such beneficial microorganisms regulates and determines the final flavor of the food. The resulted fermented food is consequently enriched in various health benefits to humans as documented by many researchers. The effects of these benefits are crucial, especially to individuals with very little access to a well-balanced diet.

Fermented cabbage, pikliz as eaten in Haiti, remains a good source of provitamin A, vitamin B, vitamin C, valuable minerals, and contains anti-atherogenic, and anticarcinogenic, among other medicinal properties. Due to the many health benefits of pikliz, public health officials should teach and engage their communities with such information where basic healthcare services are not readily available [67]. This meal garnishment will not eliminate nor solve their health problems, but the incorporation of pikliz, which is rich in bioactive (fermentation derived) compounds, could greatly reduce the rate of nutrition-related chronic diseases.

While Haitian cuisine is influenced by various other cuisines: from the Indigenous to the Africans, the flavor of Haitian cuisine remains independently unique to Haiti. This spicy meal garnishment, pikliz, represents the regional, ethnic, and national identities of Haitians living 
in Haiti and abroad. This analysis is subjected to serve as a contribution to particularly increase awareness of Haitian cuisine through the understanding of pikliz as related to its countless health benefits and social-cultural impact. Pikliz, the symbol of Haitian culture and cuisine.

\section{Authors' contributions}

$J \sqcup J$ led the research, drafted, and edited the manuscript. RS, DS, KLJ and NS served as co-team leader and editors. Photographs of homemade pikliz were produced by MLT. All authors, contributed as member of the research team, read, and approved the manuscript.

\section{Funding}

The authors did not receive funding from any public, government, commercial, or non-profit agencies.

\section{Availability of data and materials}

All data and materials are publicly available and are cited in the text. Mentioned of products are for information only and does not imply recommendation by the authors.

\section{Declarations}

\section{Competing interests}

The authors declare that they have no competing interests.

\section{Author details}

${ }^{1}$ University of Nevada Las Vegas, Las Vegas, NV, USA. ${ }^{2}$ Florida State University, Tallahassee, FL, USA. ${ }^{3}$ Florida International University, Miami, FL, USA. ${ }^{4}$ Florida Agricultural \& Mechanical University, Tallahassee, FL, USA. 'Lulu's Pikliz, Homestead, FL, USA

Received: 12 January 2020 Accepted: 22 March 2021

Published online: 09 April 2021

\section{References}

1. Moreno de Alba JG. Indigenismos en las "Décadas del Nuevo Mundo" de Pedro Mártir de Anglería. Nueva Rev Filol Hispánica. 1996;44(1):1-26. https:// doi.org/10.24201/nrfh.v44i1.1908.

2. de Anglería PM. Décadas del Nuevo Mundo, Tercera Década. Libro VII. Bajel: Buenos Aires; 1949.

3. McIntosh GC. The Piri Reis Map of 1513. 1st ed: University of Georgia Press; 2000

4. Rouse I. The Tainos: rise and decline of the people who greeted Columbus: Yale University Press; 1992

5. Chery R. Women and children's tribulation in Haiti: Xlibris, Corp; 2011.

6. Chou L. Chinese and other Asian pickles: Salads, Pickles, and Other Cold Foods. In: Flavor and Fortune, 10(3); 2003. Institute for the Advancement of the Science And Art Of Chinese Cuisine, pp 19, 20, 37-38. http://www.fla vorandfortune.com/ffdataaccess/article.php?ID=426.

7. Yurnet-Thomas M, Moskowitz J. Taste of Haiti: Hippocrene Books Inc; 2003.

8. Hall MR. Historical dictionary of Haiti: Scarecrow Press; 2012.

9. Raichlen S. The barbecue bible; 2008.

10. McGee H. On food and cooking: the science and lore of the kitchen. New York: Scribner; 2004.

11. Pickle Bill Fact Sheet 2008. https://web.archive.org/web/20080313102803/ http://www.mda.state.mn.us/food/business/factsheets/picklebill.htm. Accessed 6 Oct 2019.

12. Rhee M-S, Lee S-Y, Dougherty RH, Kang D-H. Antimicrobial effects of mustard flour and acetic acid against escherichia coli 0157:H7, listeria monocytogenes, and salmonella enterica serovar typhimurium. App Environ Microbiol. 2003;69(5):2959-63. https://doi.org/10.1128/AEM.69.5.2 959-2963.2003. Accessed 6 Apr 2020.

13. Green N. Pikliz: a spicy Haitian condiment gets a lot of love in South Florida's food scene; 2019

14. Sak Pase Pikliz Piment Pique, 16 fl oz 2019. https://www.walmart.com/ip/Sa k-Pase-Pikliz-Piment-Pique-16-fl-oz/21961769.

15. Guixens Food Group Madame Gougousse Pickled Salad, 32 oz 2019. https:// www.walmart.com/ip/Guixens-Food-Group-Madame-Gougousse-Pickled-Sala d-32-oz/215506472.
16. Briggs T. Couple moves from New York City to Fargo to start Caribbean restaurant; 2018

17. Ingram C. The cook's guide to vegetables: Hermes House; 2000.

18. USDA. Database table for raw cabbage per 100 g. US Dep Agric Natl Nutr Database Stand Ref Version SR-27; 2014. https://fdc.nal.usda.gov/fdc-app. html\#/food-details/169975/nutrients.

19. Science of pickles: fascinating pickle facts. Explor Museum Sci Art Hum Percept 2018. http://www.exploratorium.edu/cooking/pickles/history.html.

20. Lee YC. Kimchi: the famous fermented vegetable product in Korea. Food Rev Int. 1991;7(4):399-415. https://doi.org/10.1080/87559129109540920.

21. Skrabec QR. In: Biogr HJHA, editor. A momentous year. 1st ed. Jefferson: McFarland \& Company, Inc; 2009. p. 73.

22. Kwon DY, Jang D-J, Yang HJ, Chung KR. History of Korean gochu, gochujang, and kimchi. J Ethn Foods. 2014;1(1):3-7. https://doi.org/10.1016/ j.jef.2014.11.003.

23. Katz SH, Weaver WW. Encyclopedia of food and culture. 1st ed. New York: Scribner; 2003.

24. Of cabbages and celts. Aggie Hortic 2013:10-9. https://aggie-horticulture.ta mu.edu/archives/parsons/publications/vegetabletravelers/cabbage.html.

25. Wu Y, Feng $X$, Jin $Y$, Wu Z, Hankey W, Paisie C, et al. A novel mechanism of indole-3-carbinol effects on breast carcinogenesis involves induction of Cdc25A degradation. Cancer Prev Res. 2010;3(7):818-28. https://doi.org/1 0.1158/1940-6207.CAPR-09-0213.

26. Dinkova-Kostova AT, Kostov RV. Glucosinolates and isothiocyanates in health and disease. Trends Mol Med. 2012;18(6):337-47. https://doi.org/10.1016/j. molmed.2012.04.003

27. Tse G, Eslick GD. Cruciferous vegetables and risk of colorectal neoplasms: a systematic review and meta-analysis. Nutr Cancer. 2014;66(1):128-39. https://doi.org/10.1080/01635581.2014.852686

28. Chemical Entities of Biological Interest (ChEBI), The European Bioinformatics Institute (EBI). indole-3-methanol (CHEBI:24814). 2019. www.ebi.ac.uk.

29. II PN, Kim JK, Park WT, Cho JW, Lim YP, Park SU. An efficient protocol for genetic transformation of watercress (Nasturtium officinale) using Agrobacterium rhizogenes. Mol Biol Rep. 2011:38(8):4947-53. https://doi. org/10.1007/s11033-010-0638-5.

30. Ausmus S. Image number K11611-1. Agric Res Serv USDA. 2016; https:// www.ars.usda.gov/oc/images/photos/nov04/k11611-1/.

31. Schifferstein HNJ, Wehrle T, Carbon C-C. Consumer expectations for vegetables with typical and atypical colors: the case of carrots. Food Qual Prefer. 2019;72:98-108. https://doi.org/10.1016/j.foodqual.2018.10.002.

32. Howell BF, Schifferstein HNJ. How neutral coloured backgrounds affect the attractiveness and expensiveness of fresh produce. Food Qual Prefer. 2019. 78:103718. https://doi.org/10.1016/j.foodqual.2019.05.018.

33. Rubatsky VE, Quiros CF, Siman PW. Carrots and related vegetable Umbelliferae: CABI Publishing; 1999.

34. Yeager $\mathrm{S}$. The Doctors book of food remedies: the newest discoveries in the power of food to cure and prevent health problems, from aging and diabetes to ulcers and yeast infections: Rodale Press; 1997.

35. Brown E. The complete idiot's guide to smoothies. Westminster: Penguin; 2005

36. Gisslen W. Professional cooking, college version: Wiley; 2010.

37. Zidorn C, Jöhrer K, Ganzera M, Schubert B, Sigmund EM, Mader J, et al. Polyacetylenes from the apiaceae vegetables carrot, celery, fennel, parsley, and parsnip and their cytotoxic activities. J Agric Food Chem. 2005;53(7): 2518-23. https://doi.org/10.1021/jf048041s.

38. Baranska M, Schulz H, Baranski R, Nothnagel T, Christensen LP. In situ simultaneous analysis of polyacetylenes, carotenoids and polysaccharides in carrot roots. J Agric Food Chem. 2005:53(17):6565-71. https://doi.org/10.1021/ff0510440.

39. Garrod B, Lewis BG, Coxon DT. Cis-heptadeca-1,9-diene-4,6-diyne-3,8-diol, an antifungal polyacetylene from carrot root tissue. Physiol Plant Pathol. 1978. 13(2):241-6. https://doi.org/10.1016/0048-4059(78)90039-5.

40. Czepa A, Hofmann T. Structural and sensory characterization of compounds contributing to the bitter off-taste of carrots (Daucus carota L.) and carrot puree. J Agric Food Chem. 2003:51. https://doi.org/10.1021/jf034085+.

41. Kurosaki F, Nishi A. A methyltransferase for synthesis of the phytoalexin 6methoxymellein in carrot cells. FEBS Lett. 1988;227(2):183-6. https://doi. org/10.1016/0014-5793(88)80894-9.

42. O'Neil MJ, Heckelman PE, Koch CB, Roman KJ. The Merck Index - an encyclopedia of chemicals, drugs, and biologicals. Hoboken: Wiley; 2006.

43. WHO/UNICEF. Global prevalence of vitamin A deficiency. WHO micronutrient deficiency information system (mdis), working paper no 2 , WHO/NUT/95.3. Geneva: World Heal Organ Nation's Child Fund; 1995. 
44. Fuentes-Barría H, Muñoz PD. Influencia de los compuestos bioactivos de betarraga (Beta vulgaris L) sobre el efecto cardio-protector: Una revisión narrativa. Rev Chil Nutr. 2018;45(2):178-82. https://doi.org/10.4067/S071775182018000300178 .

45. Morris MC, Wang Y, Barnes LL, Bennett DA, Dawson-Hughes B, Booth SL. Nutrients and bioactives in green leafy vegetables and cognitive decline. Neurology. 2018;90(3):e214-22. https://doi.org/10.1212/WNL. 0000000000004815

46. Institute of Medicine. Food and nutrition board. Dietary Reference Intakes for Vitamin A, Vitamin K, Arsenic, Boron, Chromium, Copper, lodine, Iron, Manganese, Molybdenum, Nickel, Silicon, Vanadium, and Zinc. Washington, DC: National Academies Press; 2001. https://doi.org/10.17226/10026.

47. Gerster H. Vitamin A-functions, dietary requirements and safety in humans. Int J Vitam Nutr Res. 1997;67:71-90.

48. Futoryan T, Gilchrest BA. Retinoids and the skin. Nutr Rev. 2009;52(9):299310. https://doi.org/10.1111/j.1753-4887.1994.tb01461.x.

49. Hinds TS, West WL, Knight EM. Carotenoids and retinoids: a review of research, clinical, and public health applications. J Clin Pharmacol. 1997; 37(7):551-8. https://doi.org/10.1002/j.1552-4604.1997.tb04336.x.

50. Ross AC, Gardner EM. The function of vitamin A in cellular growth and differentiation, and its roles during pregnancy and lactation. In: Allen $\mathrm{L}_{\text {, }}$ King J, Lönnerdal B, editors. Nutr. Regul. Dur. Pregnancy, Lact. Infant Growth. Boston: Springer; 1994. p. 187-200. https://doi.org/10.1007/ 978-1-4899-2575-6_15

51. Ross AC. Vitamin A and retinoids. In: Shils ME, Olson JA, Shike M, Ross AC, editors. Mod. Nutr. Heal. Dis. 9th ed. Baltimore: Lippincott, Williams and Wilkins; 1999. p. 305-27. https://doi.org/10.1093/ajen/70.5.948.

52. Ross AC, Stephensen CB. Vitamin A and retinoids in antiviral responses. FASEB J. 1996;10(9):979-85. https://doi.org/10.1096/fasebj.10.9.8801180

53. Semba RD. The role of vitamin $A$ and related retinoids in immune function. Nutr Rev. 2009;56(1):S38-48. https://doi.org/10.1111/j.1753-4 887.1998.tb01643.x.

54. Ross DA. Vitamin A and public health: challenges for the next decade. Proc Nutr Soc. 1998:57(01):159-65. https://doi.org/10.1079/PNS19980022.

55. Harbige LS. Nutrition and immunity with emphasis on infection and autoimmune disease. Nutr Heal. 1996;10(4):285-312. https://doi.org/10.1177/ 026010609601000401.

56. Josephson E, Vinyals L. An Assessment of the Haitian MSPP's Readiness to Establish a Contracting Function. Bethesda; 2012. https://thinkwell.global/ wp-content/uploads/2014/11/An-Assessment-of-the-Haitian-MSPPs-Rea diness-to-Establish-a-Contracting-Function-ThinkWell.pdf.

57. Haiti. In: Health in the Americas, Country Vol. Pan American Health Organization. 2012. http://www.paho.org/salud-en-las-americas-2012/index. php?option=com_docman\&task=doc_view\&gid=134\&ltemid=.

58. Badjona A, Adubofuor J, Amoah I, Diako C. Valorisation of carrot and pineapple pomaces for rock buns development. Sci African. 2019;In Press. https://doi.org/10.1016/j.sciaf.2019.e00160.

59. Hedrén E, Diaz V, Svanberg U. Estimation of carotenoid accessibility from carrots determined by an in vitro digestion method. Eur J Clin Nutr. 2002; 56(5):425-30. https://doi.org/10.1038/sj.ejcn.1601329.

60. Poor CL, Bierer TL, Merchen NR, Fahey GC, Erdman JW. The accumulation of $\alpha$ - and $\beta$-carotene in serum and tissues of preruminant calves fed raw and steamed carrot slurries. J Nutr. 1993;123(7):1296-304. https://doi.org/10.1 093/jn/123.7.1296.

61. Zhou JR, Gugger ET, Erdman JW. The crystalline form of carotenes and the food matrix in carrot root decrease the relative bioavailability of beta- and alpha-carotene in the ferret model. J Am Coll Nutr. 1996;15(1):84-91. https:// doi.org/10.1080/07315724.1996.10718569.

62. Rock CL, Lovalvo JL, Emenhiser C, Ruffin MT, Flatt SW, Schwartz SJ. Bioavailability of $\beta$-carotene is lower in raw than in processed carrots and spinach in women. J Nutr. 1998;128(5):913-6. https://doi.org/10.1 093/jn/128.5.913.

63. Roels OA, Trout M, Dujacquier R. Carotene balances on boys in Ruanda where vitamin A deficiency is prevalent. J Nutr. 1958;65(1):115-27. https:// doi.org/10.1093/jn/65.1.115

64. Dimitrov NV, Meyer C, Ullrey DE, Chenoweth W, Michelakis A, Malone W, et al. Bioavailability of beta-carotene in humans. Am J Clin Nutr. 1988;48(2): 298-304. https://doi.org/10.1093/ajcn/48.2.298.

65. Shiau A, Mobarhan S, Stacewicz-Sapuntzakis M, Benya R, Liao Y, Ford C, et al. Assessment of the intestinal retention of beta-carotene in humans. J
Am Coll Nutr. 1994;13(4):369-75. https://doi.org/10.1080/07315724.1994.1 0718424.

66. Jalal F, Nesheim MC, Agus Z, Sanjur D, Habicht JP. Serum retinol concentrations in children are affected by food sources of beta-carotene, fat intake, and anthelmintic drug treatment. Am J Clin Nutr. 1998;68(3):623-9. https://doi.org/10.1093/ajcn/68.3.623.

67. Louis-Jean J, Cenat K, Sanon D, Stvil R. Coronavirus (COVID-19) in Haiti: a call for action. J Community Heal. 2020;45(3):437-9. https://doi.org/10.1007/s1 0900-020-00825-9.

\section{Publisher's Note}

Springer Nature remains neutral with regard to jurisdictional claims in published maps and institutional affiliations.
Ready to submit your research? Choose BMC and benefit from:

- fast, convenient online submission

- thorough peer review by experienced researchers in your field

- rapid publication on acceptance

- support for research data, including large and complex data types

- gold Open Access which fosters wider collaboration and increased citations

- maximum visibility for your research: over $100 \mathrm{M}$ website views per year

At BMC, research is always in progress.

Learn more biomedcentral.com/submissions 